\title{
Million Colony Forming Units
}

National Cancer Institute

\section{Source}

National Cancer Institute. Million Colony Forming Units. NCI Thesaurus. Code C68896.

A unit of measurement of viable cell quantity equal to $10 \mathrm{E} 6$ colony forming units (10E6 CFU). 